\title{
IMPLEMENTASI PENDIDIKAN KARAKTER BANGSA PADA PEMBELAJARAN MATEMATIKA SMPN 5 BATUSANGKAR
}

\author{
Dona Afriyani \\ Program Studi Tadris Matematika, Jurusan Tarbiyah STAIN Batusangkar \\ Korespondensi: Jln. Sudirman No.137 Kubu Rajo Lima Kaum, \\ Batusangkar, Sumatera Barat. \\ e-mail: donaafriyani@gmail.com
}

\begin{abstract}
Goverment will about the implementation of character education needs for appropriateness of 'Kurikulum Tingkat Satuan Pendidikan' (KTSP) in form of modification of learning tools at all subjects. Mathematics as one of many general subjects, for example, needs to integrate character values in order to have good characters. Therefore, it is better to explore preparation, implementation, evaluation, and all teachers' difficulties in implementing character education in teaching Math at junior high school. Through descriptive qualitative research, this study had been successful to show a fact about the information that was relevant with the implementation.
\end{abstract}

Kata kunci: pendidikan karakter, pembelajaran matematika

\section{PENDAHULUAN}

$\mathrm{P}$ ersoalan karakter bangsa kini menjadi sorotan tajam masyarakat. Sorotan tersebut mengenai berbagai aspek kehidupan yang tertuang dalam berbagai tulisan di media cetak, wawancara, dialog, dan gelar wicara di media elektronik. Salah satu upaya preventif yang dapat dilakukan untuk mengatasi (paling tidak mengurangi) masalah karakter bangsa ialah melalui penanaman nilai-nilai karakter bangsa sedini mungkin kepada anak sekolah.

Pemerintah melalui Kementerian Pendidikan Nasional (Kemendiknas) dan Badan Penelitian dan Pengembangan (Balitbang) Pusat Kurikulum sudah merancang suatu grand disain pengembangan karakter bangsa serta pedoman pengembangan pendidikan budaya dan karakter bangsa tahun 2010. Dalam pedoman tersebut dijelaskan tentang pengembangan nilai-nilai pendidikan budaya dan karakter bangsa diintegrasikan dalam setiap pokok bahasan dari setiap mata pelajaran. Oleh karena itu, guru dan sekolah perlu mengintegrasikan nilai-nilai yang dikembangkan dalam pendidikan budaya dan karakter bangsa ke dalam Kurikulum Tingkat Satuan Pendidikan (KTSP), Silabus dan Rencana Program Pembelajaran (RPP) yang sudah ada.

Pendidikan karakter bukan sebuah mata pelajaran, tetapi ia diintegrasikan pada seluruh mata pelajaran yang ada di setiap jenjang pendidikan. Hakikat pendidikan karakter yaitu bagaimana menanamkan kebiasaaan tentang hal-hal yang baik dalam kehidupan sehingga peserta didik memiliki kesadaran dan pemahaman yang tinggi, serta kepedulian dan komitmen untuk menerapkan kebajikan dalam kehidupan sehari-hari (Mulyasa, 
2011). Dengan demikian, istilah karakter berkaitan dengan kepribadian (personality) seseorang, sehingga ia disebut orang yang berkarakter jika perilakunya sesuai dengan etika atau kaidah moral.

Menurut Dinas Pendidikan Kabupaten Tanah Datar, semua sekolah mulai dari sekolah dasar sampai sekolah menengah atas sudah diminta untuk mengimplementasikan pendidikan karakter di sekolah masing-masing. Hal ini ditandai dengan jenis tagihan berupa perangkat pembelajaran berbasis pendidikan karakter yang diminta para pengawas/penilik sekolah dari setiap guru. SMPN 5 Batusangkar sebagai salah satu sekolah unggulan dan favorit di daerah ini langsung melakukan perubahan, salah satunya dengan menetapkan visi, misi, dan indikator misi sekolah yang berorientasi pada terwujudnya peserta didik yang cerdas, jujur, disiplin, tanggungjawab, dan memiliki sikap religius. Implementasi pendidikan karakter di sekolah tersebut berpedoman pada pedoman yang dikeluarkan oleh Depdiknas tahun 2010. Seperti yang diketahui, bahwa pedoman tersebut masih bersifat umum, belum ada penjabaran operasional pengintegrasian nilai karakter untuk setiap mata pelajaran disetiap jenjang pendidikan.

Akhirnya pertanyaan muncul, yakni bagaimana SMPN 5 Batusangkar mengimplementasikan pendidikan karakter. Pengembangan karakter di sekolah memiliki dua konteks, yaitu konteks makro dan konteks mikro. Secara makro pengembangan karakter dibagi dalam tiga tahap, yaitu perencanaan, pelaksanaan, dan evaluasi hasil. Sedangkan dalam konteks mikro, berpusat pada satuan pendidikan secara holistic (Mulyasa, 2011). Salah satu ruang lingkup pengembangan pendidikan karakter di satuan pendidikan ialah pada kegiatan belajar mengajar yang dilaksanakan de- ngan menggunakan pendekatan integrasi dalam semua mata pelajaran, khususnya untuk mata pelajaran selain Pendidikan Agama Islam dan Pendidikan Kewarganegaraan.

Matematika sebagai mata pelajaran yang dipelajari peserta didik di setiap satuan pendidikan sejauh ini masih dipandang sebagai suatu mata pelajaran yang sulit untuk diajarkan maupun untuk dipelajari (Cockcroft dalam Wahyudin, 2011). Padahal pembelajaran matematika berpotensi sebagai salah satu media pembiasaan perilaku teliti dan jujur. Selain itu, pembelajaran matematika melatih beberapa kemampuan sehingga mereka memiliki sikap kritis, kreatif, dan komunikatif. Hal ini terbukti dari tujuan pembelajaran matematika yang tercantum pada Permen No. 22 tahun 2006. Di dalam NCTM (2000:50) disebutkan bahwa "kemampuan dalam matematika akan membuka pintu untuk masa depan yang produktif. Lemah dalam matematika membiarkan pintu tersebut tertutup". Untuk itu, para peserta didik harus mendapatkan pembelajaran matematika yang terbaik agar mereka bisa mencapai karier di dunia yang terus-menerus berubah dengan cepat.

Perancangan dan pengembangan pembelajaran matematika yang aktif untuk mewujudkan agar peserta didik cakap bermatematika tidaklah mudah. Hal ini terkait dengan karakteristik matematika yang merupakan bidang studi yang sangat berhirarkis. Terwujudnya pembelajaran matematika yang lebih mengedepankan munculnya aktivitas matematika juga tergantung pada karakter peserta didiknya, yaitu kerja keras, tekun, teliti, pantang menyerah, kreatif, dan rasa ingin tahu. Dari sini, juga dapat dilihat potensi pendidikan karakter melalui pembelajaran matematika yang berkualitas, dengan cara mengingtegrasikan 
nilai-nilai pada setiap pokok bahasan pada pembelajaran matematika.

Agar program unggulan pemerintah ini bisa sukses, tentunya keprofesionalan guru dalam mengimplementasikan pendidikan karakter memegang andil yang besar. Fenomena di lapangan khususnya pada pembelajaran matematika di SMPN 5 Batusangkar menunjukkan bahwa guru-guru matematika sebagai pelaksana inti masih mempunyai beberapa pertanyaan tentang bagaimana mengintegrasikan nilai-nilai karakter dalam mata pelajaran, khususnya mata pelajaran matematika. Pertanyaan tersebut di antaranya; Apakah ke-18 nilai tersebut perlu dan dapat diintegrasikan ke dalam mata pelajaran matematika?; Strategi pembelajaran seperti apa yang harus dirancang?; Bagaimana cara membagi alokasi waktunya?; Bagaimana cara melakukan penilaiannya?. Pertanyaanpertanyaan di atas sering dilontarkan oleh guru pada acara seminar dan workshop tentang integrasi pendidikan karakter dalam pembelajaran matematika. Dari sini, terlihat bahwa sebetulnya guru belum siap untuk melaksanakan program pemerintah ini dengan baik.

Di lain pihak, para pengawas sekolah meminta setiap guru matematika dapat merancang, mengembangkan dan melaksanakan RPP berbasis pendidikan karakter. Tentunya muncul pertanyaan, "bagaimanakah cara guru matematika mengimplementasikan pendidikan karakter pada mata pelajaran matematika?" Dengan demikian, masalah penelitian dirumuskan sebagai berikut; Bagaimana model pengembangan silabus dan RPP matematika berbasis pendidikan karakter yang dikembangkan oleh guru SMPN 5 Batusangkar?, Bagaimana pelaksanaan integrasi nilai-nilai karakter bangsa pada pembelajaran matematika di SMPN 5 Batusangkar?, Hambatan-hambatan apa sajakah yang dihadapi dalam perencanaan dan penerapan pendidikan ka- rakter pada pembelajaran matematika di SMPN 5 Batusangkar?

\section{KAJIAN TEORITIS}

\section{Implementasi Pendidikan Karakter di Sekolah}

Implementasi merupakan suatu proses penerapan ide, konsep, kebijakan, dan inovasi dalam suatu tindakan praktis sehingga memberikan dampak, baik berupa perubahan pengetahuan, keterampilan, nilai, dan sikap (Mulyasa, 2009). Implementasi pengembangan karakter bertujuan agar generasi penerus bangsa memiliki nilai-nilai luhur bangsa Indonesia, seperti yang tercantum pada kelima sila Pancasila.

Di dalam Grand Disain pembangunan karakter bangsa tahun 2010 disebutkan ada tujuh lingkup sasaran pembangunan karakter, yaitu lingkup keluarga, lingkup satuan pendidikan, lingkup pemerintah, lingkup masyarakat sipil, lingkup masyarakat politik, lingkup dunia usaha dan industri, serta lingkup media. Untuk lingkup satuan pendidikan pengembangan karakter dilakukan dengan menggunakan (a) pendekatan terintegrasi dalam semua mata pelajaran, (b) pengembangan budaya satuan pendidikan, (c) pelaksanaan kegiatan kokurikuler dan ekstrakurikuler, serta (d) pembiasaan prilaku dalam kehidupan di lingkungan satuan pendidikan.

Khusus implementasi pengembangan karakter menggunakan pendekatan integrasi dalam mata pelajaran, Puskur (2010) mengatur langkah-langkah pengintegrasian ke dalam mata pelajaran, yaitu sebagai berikut: (1) mengkaji Standar Komptensi (SK) dan Kompetensi Dasar (KD) pada Standar Isi (SI) untuk menentukan apakah nilai-nilai karakter bangsa yang tercantum itu sudah tercakup di dalamnya; (2) membuat tabel yang memperlihatkan keterkaitan antara SK dan KD dengan nilai dan 
indikator untuk menentukan nilai yang akan dikembangkan; (3) mencantumkan nilai-nilai budaya dan karakter bangsa dalam tabel point 2 ke dalam silabus; (4) mencantumkan nilai-nilai yang sudah tertera dalam silabus ke dalam RPP; (5) mengembangkan proses pembelajaran peserta didik secara aktif yang memungkinkan peserta didik memiliki kesempatan melakukan internalisasi nilai dan menunjukkannya dalam perilaku yang sesuai; (6) memberikan bantuan kepada peserta didik, baik yang mengalami kesulitan untuk menginternalisasi nilai maupun untuk menunjukkannya dalam perilaku.

Merujuk pada prosedur di atas, maka pengintegrasian pendidikan karakter ke dalam matapelajaran harus dimulai dari silabus yang selanjutnya dituangkan ke dalam RPP. Di dalam RPP harus tergambar semua kegiatan yang akan dilakukan dalam pelaksanaan pembelajaran, serta nilai-nilai karakter yang mungkin dapat dikembangkan melalui kegiatan tersebut.

Menurut Permen No 41 tahun 2007, Standar proses meliputi perencanaan proses pembelajaran, pelaksanaan proses pembelajaran, penilaian hasil pembelajaran, dan pengawasan proses pembelajaran untuk terlaksananya proses pembelajaran yang efektif dan efisien. Perencanaan proses pembelajaran meliputi silabus dan rencana pelaksanaan pembelajaran (RPP) yang memuat identitas mata pelajaran, standar kompetensi (SK), kompetensi dasar (KD), indikator pencapaian kompetensi, tujuan pembelajaran, materi ajar, alokasi waktu, metode pembelajaran, kegiatan pembelajaran, penilaian hasil belajar, dan sumber belajar.

Pelaksanaan pembelajaran terbagi ke dalam tiga kegiatan yaitu kegiatan pendahuluan, kegiatan inti dan kegiatan penutup. Kegiatan pendahuluan adalah kegiatan yang menuntut guru untuk mempersiapkan peserta didik dalam proses pembelajaran. Kegiatan inti merupakan proses pembelajaran untuk mencapai KD yang dilakukan secara interaktif, inspiratif, menyenangkan, menantang, memotivasi peserta didik untuk berpartisipasi aktif, serta memberikan ruang yang cukup bagi prakarsa, kreativitas, dan kemandirian sesuai dengan bakat, minat dan perkembangan fisik serta psikologis peserta didik. Sedangkan kegiatan penutup dilakukan untuk membantu peserta didik membuat kesimpulan tentang pembelajaran yang telah dilakukan, melakukan penilaian, merencanakan tindak lanjut, dan menyampaikan rencana pembelajaran berikutnya. Semua kegiatan ini dituangkan dalam Rencana Pelaksanaan Pembelajaran (RPP).

Pada implementasi pengembangan pendidikan karakter, di dalam RPP harus tergambar semua kegiatan yang akan dilakukan dalam pelaksanaan pembelajaran, serta nilai-nilai karakter yang mungkin dapat dikembangkan melalui kegiatan tersebut. Kegiatan pembelajaran yang dirancang memungkinkan peserta didik secara aktif dapat mengalami situasi nyata untuk mencapai kompetensi dan melakukan internalisasi nilai serta menunjukkannya dalam perilaku yang sesuai. Jadi, guru harus terampil menerapkan strategi dan metode pembelajaran aktif.

Untuk melihat perkembangan nilai-nilai karakter yang sudah tertanam pada diri peserta didik, tidak bisa menggunakan penilaian berbentuk "paper and pencil test", karena hanya dapat mengukur aspek kognitif saja. Merujuk pada prinsip berkelanjutan, maka penilaian dilakukan secara terus menerus, setiap saat guru berada di kelas atau di sekolah. Model penilaian yang dapat digunakan seperti Model anecdotal record (catatan yang dibuat guru ketika melihat adanya perilaku 
yang berkenaan dengan nilai yang dikembangkan) selalu dapat digunakan guru. Selain itu, guru dapat pula memberikan tugas yang berisikan suatu persoalan atau kejadian yang memberikan kesempatan kepada peserta didik untuk menunjukkan nilai yang dimilikinya.

Dari hasil pengamatan, catatan anekdotal, tugas, laporan, dan sebagainya, guru dapat memberikan kesimpulan atau pertimbangan tentang pencapaian suatu indikator atau bahkan suatu nilai. Kesimpulan atau pertimbangan itu dapat dinyatakan dalam pernyataan kualitatif Belum Terlihat (BT), Mulai Terlihat (MT), Mulai Berkembang (MB), Membudaya (MK)

\section{Pendidikan Karakter pada Pem- belajaran Matematika}

Pembelajaran matematika yang berkualitas merupakan salah satu media dalam pengembangan karakter bangsa. Melalui pembelajaran matematika, nilainilai karakter bangsa diinternalisasikan ke dalam setiap pokok bahasan yang ada pada mata pelajaran matematika. Internalisasi dapat dilakukan dengan cara memberikan keteladanan dari tokohtokoh matematika terkemuka, memunculkan rasa ingin tahu, membiasakan mereka melakukan koreksi, menumbuhkan semangat pantang menyerah dalam memecahkan persoalan, dan lain sebagainya. Dengan demikian, menjadikan peserta didik menjadi individu yang berkarakter juga merupakan tujuan pembelajaran matematika masa kini.

Karakter dan matematika sebetulnya dua kata yang memiliki konteks yang berbeda, tetapi keduanya dapat dipadukan dengan cara merelasikan tujuan pembelajaran dan karakteristik matematika dengan nilai-nilai karakter bangsa. Terdapat lima nilai karakter yang dapat diinternalisasikan melalui pembelajaran matematika kelas 7-9, yaitu teliti, tekun, kerja keras, rasa ingin tahu, dan pantang menyerah (Puskur,
2010). Relasi ini akan dibahas lebih lanjut, namun terlebih dahulu perlu dibahas tentang matematika dan pembelajaran matematika.

Matematika berasal dari bahasa latin manthanein atau mathema yang berarti belajar atau hal yang dipelajari (Fajar, 2007). Elea Tinggih dalam Erman (2001) menambahkan bahwa matematika berarti ilmu pengetahuan yang diperoleh dengan bernalar. Kitcher dalam Hamzah (2008) mengklaim bahwa matematika terdiri atas komponen-komponen: (1) Bahasa (language): bahasa matematika diwujudkan dalam bentuk lambang atau simbol yang memiliki makna tersendiri, (2) Peryataan (statement): biasanya ditemukan dalam bentuk logika matematika, (3) Pertanyaan (questions): Persoalan matematika yang belum terpecahkan, (4) Alasan (reason): yang memerlukan alasan secara argumentatif dalam memecahkan masalah matematika. Mengacu kepada pendapat dua ahli di atas, dapat disimpulkan bahwa matematika adalah ilmu pengetahuan yang terdiri atas bahasa, pernyataan, pertanyaan, dan alasan untuk mengembangkan kemampuan penalaran.

Pembelajaran merupakan suatu upaya menciptakan kondisi yang memungkinkan peserta didik dapat belajar. Pembelajaran lebih menekankan pada bagaimana upaya guru mendorong atau menfasilitasi peserta didik belajar, bukan pada apa yang dipelajari peserta didik. Istilah pembelajaran lebih menggambarkan bahwa peserta didik lebih banyak berperan dalam mengkonstruksikan pengetahuan bagi dirinya dan bahwa pengetahuan itu bukan hasil proses transformasi dari guru (Muliyardi, 2002).

Dalam hubungannya dengan pelajaran matematika, Nikson (1992) dalam Muliyardi (2002) mengemukakan bahwa pembelajaran matematika adalah upaya membantu peserta didik untuk mengkonstruksi konsep-konsep atau prinsip-prinsip matematika dengan ke- 
mampuannya sendiri melalui proses internalisasi sehingga konsep atau prinsip itu terbangun kembali. Dengan demikian, pada pembelajaran matematika peserta didik dibiasakan untuk memperoleh pemahaman melalui pengalaman tentang sifat-sifat yang dimiliki dan tidak dimiliki dari suatu objek. Dengan pengamatan terhadap contohcontoh dan bukan contoh diharapkan peserta didik mampu menangkap pengertian suatu konsep.

Prinsip-prinsip dan standar dari NCTM (2000) memberikan lima standar isi matematika, yakni: Bilangan dan Operasinya; Aljabar; Geometri; Pengukuran; Analisis Data dan Probabilitas. Setiap standar isi memuat sejumlah tujuan untuk semua kelompok kelas. Meskipun kelima standar isi yang sama berlaku untuk semua kelas, tetapi setiap kelas memiliki penekanan yang berbeda. Selain standar isi, NCTM juga merumuskan lima standar proses pembelajaran matematika, yaitu pemecahan masalah, pemahaman dan bukti, komunikasi, hubungan, dan penyajian. Kelima standar proses ini dipandang sebagai sesuai yang tidak terpisah dari standar isi kurikulum matematika.

Nilai-nilai karakter yang mungkin dapat ditumbuhkan pada setiap tujuan pembelajaran matematika di atas menurut Armiati (2011) yaitu rasa ingin tahu, gemar membaca, teliti, tekun, kreatif, kerja keras, tanggung jawab, cinta damai, dan demokrasi. Di dalam pedoman pengembangan karakter PUSKUR, nilai-nilai yang dikembangkan pada pembelajaran matematika hanya teliti, tekun, kerja keras, dan rasa ingin tahu. Artinya, kita diberi kebebasan dalam mengembangkan nilai karakter bangsa pada pembelajaran matematika.

Nilai-nilai karakter yang sudah diidentifikasikan sebelumnya, diinter- nalisasikan melalui kegiatan pembelajaran matematika yang meaningful. Pembelajaran bermakna tidak hanya belajar untuk mengetahui, tetapi belajar untuk melakukan, belajar menjiwai, belajar bagaimana seharusnya belajar, dan belajar berasosiasi dengan sesame teman (Erman, 2003). Merancang kegiatan bermakna berpedoman pada standar proses.

Berdasarkan Permen No 41 tahun 2007, standar proses meliputi perencanaan proses pembelajaran, pelaksanaan proses pembelajaran, penilaian hasil pembelajaran, dan pengawasan proses pembelajaran. Perencanaan proses pembelajaran meliputi silabus dan rencana pelaksanaan pembelajaran (RPP) yang memuat identitas mata pelajaran, standar kompetensi (SK), kompetensi dasar (KD), indikator pencapaian kompetensi, tujuan pembelajaran, materi ajar, alokasi waktu, metode pembelajaran, kegiatan pembelajaran, penilaian hasil belajar, dan sumber belajar.

Merujuk pada prinsip pendidikan karakter yaitu melalui mata pelajaran, maka pengintegrasian pendidikan karakter ke dalam matapelajaran harus dimulai dari silabus yang selanjutnya dituangkan ke dalam RPP. Di dalam RPP harus tergambar semua kegiatan yang akan dilakukan dalam pelaksanaan pembelajaran, serta nilai-nilai karakter yang mungkin dapat dikembangkan melalui kegiatan tersebut.

Berdasarkan pengertian pendidikan menurut UU No 20 tahun 2003 terlihat bahwa kegiatan pembelajaran hendaknya dilakukan dengan memberikan kesempatan kepada peserta didik secara aktif untuk mengembangkan potensinya. Untuk itu pendidik harus mampu menerapkan berbagai strategi pada pembelajaran matematika, diantaranya yaitu; PAIKEM, pendekatan kontekstual, pendekatan metakognitif, PMRI, dan lainlain. 


\section{METODE PENELITIAN}

\section{Jenis dan Subjek Penelitian}

Penelitian ini dilaksanakan dengan menggunakan pendekatan kualitatif. Pendekatan kualitatif dilakukan dalam bentuk observasi, wawancara dan dokumentasi untuk melihat model implementasi pendidikan karakter pada pembelajaran matematika di SMPN 5 Batusangkar.

\section{Pengembangan Instrumen, Peng- umpulan dan Analisis Data}

Pengembangan instrumen dan pengumpulan data dilakukan sendiri oleh peneliti. Instrumen tersebut berupa; pedoman observasi, pedoman wawancara, serta dokumentasi. Selain itu, juga dikumpulkan artifak berupa silabus, RPP, perangkat pembelajaran lainnya sebagai sumber data.

Analisis data dalam penelitian ini melibatkan tiga komponen pokok, yaitu reduksi data, penyajian data, dan penarikan kesimpulan. Kesimpulan ini masih bersifat sementara karena akan dilihat kembali keabsahannya sampai diperoleh kesimpulan yang sahih sebagai simpulan akhir.

\section{HASIL PENELITIAN}

Berdasarkan hasil analisis data diperoleh hasil penelitian yang diformulasikan dalam bentuk proposisi mayor dan proposisi minor sebagai berikut;

Proposisi mayor: Terjadi adaptasi model silabus matematika KTSP menjadi model silabus berbasis pendidikan karakter. Proposisi minor 1: Komponen silabus berbasis pendidikan karakter berisi identitas silabus (nama sekolah, kelas, mata pelajaran, semester), standar kompetensi, kompetensi dasar, materi pokok/pembelajaran, kegiatan pembelajaran, indikator, pe- nilaian, dan nilai karakter. Proposisi minor 2: Terdapat dua model format silabus matematika yang dikembangkan oleh guru SMPN 5 Batusangkar. Perbedaan kedua format terletak pada posisi kolom nilai karakter terhadap kolom komponen lainnya. Format pertama memposisikan kolom nilai karakter sesudah kolom kegiatan pembelajan, sedangkan format kedua, meletakkannya sesudah kolom penilaian.

Proposisi mayor: Selain menambah komponen nilai karakter, pengembangan silabus matematika berbasis pendidikan karakter juga dilakukan terhadap komponen indikator pencapaian kompetensi kegiatan pembelajaran. Proposisi minor: Nilai karakter yang diintegrasikan pada mata pelajaran matematika disetiap jenjang adalah; Kelas VII yaitu mandiri, percaya diri, teliti, kreatif, benar, sistematis, ulet, cermat, sikap cermat, tepat, percaya diri; Kelas VIII yaitu demokrasi, kritis, kreatif, peduli, berpikir logis, teliti, tanggung jawab, jujur, tanggung jawab, jujur, percaya diri, inovatif, kecerdasan, peduli, dan tangguh; Kelas IX yaitu cinta ilmu, kerjasama, menghargai pendapat, santun, jujur, tanggungjawab, ingin tahu, berpikir logis, kritis, kreatif, mandiri, dan percaya diri. Proposisi minor: Kegiatan pembelajaran yang dirancang untuk nilai karakter di atas sudah memberikan pengalaman kepada peserta didik untuk mengidentifikasi, menemukan, mendiskusikan, mendemonstrasikan, menggambar, dan menyelesaikan persoalan matematika. Pengalaman-pengalaman tersebut dijadikan wahana dalam pembiasaan bersikap, sehingga nilai karakter yang diinginkan menjadi karakteristik peserta didik. Proposisi minor: Indikator pencapaian kompetensi memuat nilai karakter yang sesuai di setiap rumusannya.

Proposisi mayor: Model adaptasi Rencana Pelaksanaan Pembelajaran 
(RPP) dalam rangka menanamkan nilai karakter bangsa terlihat pada pengembangan komponen tujuan pembelajaran, rancangan kegiatan pembelajaran dan penilaian. Namun, model adaptasi tersebut hanya dijumpai pada RPP kelas VII dan VIII. Proposisi minor: Adaptasi tujuan pembelajaran yang dilakukan dengan menambahkan nilai karakter pada setiap rumusan tujuan pembelajaran. Proposisi minor: Pada kegiatan pendahuluan, guru sudah merencanakan akan melakukan penggalian pengetahuan awal setelah menyampaikan tujuan pembelajaran lewat pemberian ilustrasi masalah kontekstual yang sesuai dengan materi pertemuan tersebut. Begitujuga, pada kegiatan intinya, guru merancang aktivitas belajar sehingga peserta didik lebih banyak diminta untuk melakukan (menjelaskan, mengurutkan, menemukan, menentukan, menyederhanakan, dan menyelesaikan). Proposisi minor: Rancangan kegiatan penilaian pada RPP meliputi penilaian aspek kognitif, nilai karakter (sikap) dan psikomotor. Instrumen penilaian karakter yang digunakan adalah lembar observasi dengan skala penilaian yang didefinisikan.

Proposisi mayor: Karakteristik kegiatan pembelajaran matematika di SMPN 5 Batusangkar dalam rangka mengintegrasikan nilai karakter. Proposisi minor: metode pembelajaran yang cenderung dipakai oleh guru adalah metode pencarían informasi,kerja kelompok, dan tanya jawab. Proposisi minor: Peran guru sebagai motivator sangat terlihat selama kegiatan pembelajaran berlangsung. Motivasi yang selalu diberikan agar peserta didik memiliki keberanian untuk mengungkapkan pertanyaan dengan percaya diri dan sportif. Proposisi minor: Bimbingan yang dilakukan oleh guru berupa membantu peserta didik dalam menemukan konsep dengan cara meng- ajukan serangkaian pertanyaan yang memunculkan konflik kognitif. Proposisi minor: Guru terlihat berwibawa dalam mengajar dan sikap yang selalu tercermin adalah sikap penyanyang sehingga terjalin hubungan harmonis antara guru dan peserta didik. Proposisi minor: Pembelajaran matematika dihiasi dengan aktivitas unjuk kerja seperti mencari informasi tentang materi yang dipelajari, melakukan demonstrasi yang sesuai dengan kompetensi yang diingini, dan berdiskusi dalam kelompok memecahkan persoalan matematika. Proposisi minor: Setiap kegiatan berakhir, guru selalu meminta peserta didik melakukan refleksi dan evaluasi dari proses kerja atau pengalaman yang mereka alami, kemudian peserta didik diminta untuk menentukan sikap terhadap kendala/kelemahan dari pengalaman mereka.

Proposisi mayor: Model penilaian yang dilakukan guru matematika tidak hanya sebatas penilaian aspek kognitif saja, tetapi sudah menilai aspek afeksi (nilai karakter) dan psikomotor peserta didik. Proposisi minor 1: Guru telah mempersiapkan instrumen penilaian nontes berupa lembar observasi untuk melihat keterampilan peserta didik dan beberapa nilai karakter yang muncul pada peserta didik selama pembelajaran matematika. Proposisi minor 2: Selama pembelajaran matematika berlangsung terlihat guru selalu melakukan pemantauan terhadap perkembangan peserta didik yang berpedoman pada lembar observasi yang telah dipersiapkan sebelumnya. Proposisi minor 3: Berdasarkan hasil wawancara, diperoleh informasi bahwa hasil penilaian yang telah dilakukan oleh guru ditindak lanjuti sehingga permasalahan yang dihadapi peserta didik segera teratasi. Wujud tindak lanjut yang dilakukan guru untuk peserta didik yang belum memperoleh 
hasil yang diharapkan berupa tindakan dampingan secara langsung yang diistilahkan dengan sesi curhat, sedangkan untuk peserta didik yang memiliki potensi lebih berupa pengkaderan untuk mengikuti lomba atau olimpiade mata pelajaran, seni, dan lain sebagainya.

Proposisi mayor: Implementasi pendidikan karakter pada mata pelajaran matematika di SMPN 5 Batusangkar didukung oleh strategi yang dilakukan oleh sekolah yang mengembangkan pendidikan budaya dan karakter melalui program pengembangan diri Proposisi minorl: Semua warga sekolah harus membudayakan hidup bersih dan berpenampilan rapi dan bagus. Proposisi minor 2: Setiap kelas memiliki daftar piket setiap hari dan peserta didikpeserta didik yang piket harus bertanggung jawab atas kebersihan kelas. Proposisi minor 3: Untuk menanamkan nilai-nilai religius, sekolah mewajibkan peserta didik melaksanakan sholat Dhuha pada jam 10.00 WIB. Proposisi minor 3: Dalam pengembangan bakat dan minat, setiap jumat pertama setiap bulannya, peserta didik mengadakan pentas kreatif, dimana kelas pelaksanan menampilkan bakat dan minat mereka. Proposisi minor 4: Keunikan SMPN 5 Batusangkar yaitu tidak memiliki bel sekolah. Hal ini sengaja dilakukan oleh pihak sekolah dengan pertimbangan untuk menumbuhkan kesadaran dan sentivitas disiplin peserta didik, sehingga peserta didik dapat disiplin masuk kelas walaupun tanpa ada bunyi bel.

Proposisi mayor: Guru matematika SMPN 5 Batusangkar masih mengalami beberapa kendala dalam mengimplementasikan pendidikan karakter pada pembelajaran matematika. Proposisi minor 1: Keterbatasan buku referensi yang mudah dipelajari sebagai pedoman dalam mengembangkan silabus, RPP, dan bahan ajar. Proposisi minor 2: Belum ada pedoman khusus bagi guru yang berisi tentang indikator masing-masing nilai karakter yang dapat diinternalisasikan dalam pembelajaran matematika SMP.

\section{PEMBAHASAN}

Berdasarkan hasil penelitian tentang gambaran implementasi pendidikan karakter pada pembelajaran matematika di SMPN 5 Batusangkar, guru matematika telah melakukan modifikasi terhadap serangkaian komponen mulai dari persiapan, pelaksanaan, dan penilaian. Persiapan yang dilakukan guru matematika dalam mengintegrasikan nilai karakter dalam pembelajaran matematika yaitu mengintegrasikan nilai-nilai karakter ke dalam silabus dan RPP matematika yang sudah ada. Adaptasi silabus matematika berkarakter dengan menambahkan sebuah komponen yaitu nilai karakter. Namun, terdapat perbedaan urutan letak pada silabus di SMPN 5 Batusangkar. Perbedaan format silabus bukan merupakan suatu hal yang perlu dipermasalahan, karena prinsip pendidikan karakter yaitu guru diperbolehkan melakukan kreasi salam merancang pendidikan karakter (Supinah, 2011).

Dalam pengembangan silabus matematika berkarakter, guru mengkaji SK dan KD pada standar isi untuk menentukan nilai karakter yang akan diinternalisasikan pada peserta didik. Pengkajian nilai karakter tersebut dilaksanakan pada kegiatan MGMP, sehingga diperoleh serangkaian nilai karakter yang akan diintegrasikan pada pembelajaran matematika SMP. Keterlibatan guru dalam MGMP dalam penyusunan dan perumusan silabus berkarakter dapat menyukseskan implementasi pendidikan karakter pada setiap matapelajaran (Mulyasa, 2011). Nilai karakter yang telah dirumuskan di MGMP, kemudian disesuaikan dengan nilai karakter sekolah yang dapat dilihat 
pada visi dan misi sekolah. Nilai karakter yang tercantum dalam silabus matematika SMPN 5 Batusangkar setiap jenjangnya sudah sesuai dengan nilai karakter panduan pendidikan karakter di SMP yang dikeluarkan oleh Kemendiknas (2010). Penetapan nilai karakter merupakan salah satu dasar, selain SK dan KD, untuk menyusun kegiatan pembelajaran pada silabus matematika berkarakter (Supinah, 2011).

Rancangan kegiatan pembelajaran pada silabus matematika SMPN 5 Batusangkar sudah memberikan pengalaman kepada peserta didik untuk mencapai kompetensi yang diharapkan dan menanamkan kebiasaan untuk berbuat dengan teliti, cermat, bertanggungjawab, penuh percaya diri, dan nilai karakter lain yang sudah ditetapkan. Kegiatan yang dirancang sudah melibatkan peserta didik aktif baik perorangan atau kelompok, sehingga kegiatan pembelajaran sudah menggunakan metode yang bervariasi (Depdiknas, 2006). Pengalaman peserta didik seperti mengidentifikasi, menemukan, mendiskusikan, mendemonstrasian, menggambar, dan menyelesaikan persoalan matematika merupakan aktivitas yang dapat melatih kecakapan hidup yang meliputi semua aspek pembelajaran (Trianto, 2009). Walaupun masih ditemukan beberapa ketidaksesuaian antara beberapa kegiatan pembelajaran dengan nilai karakter yang ditetapkan, tetapi secara umum kegiatan pembelajaran berorientasi pada peserta didik. Seperti yang tertuang pada buku Panduan Pengembangan Silabus bahwa kriteria mengembangan kegiatan pembelajaran yaitu harus disusun bertujuan untuk memberikan bantuan kepada para pendidik sesuai dengan tuntunan kurikulum (Depdiknas, 2006).

Perbedaan indikator pada silabus matematika berkarakter SMPN 5 Batu- sangkar dengan silabus KTSP sebelumnya yaitu rumusannya menyuratkan nilai karakter yang diharapkan muncul dan rumusan indicator sudah mengukur aspek kognitif, afektif, dan psikomotor. Hal ini sejalan dengan pendapat Trianto (2009) bahwa indicator pencapaian kompetensi harus sesuai dengan tingkat berpikir peserta didik, berkaitan dengan $\mathrm{SK} / \mathrm{KD}$, harus menunjukkan pencapaian hasil belajar, dan mudah diukur.

Persiapan lainnya yang dilakukan guru matematika yaitu mengembangkan RPP matematika berkarakter yang berpedoman pada silabus matematika berkarakter. RPP berkarakter berfungsi untuk mengefektifkan proses pembelajaran dan pembentukan karakter peserta didik sesuai dengan apa yang direncanakan (Mulyasa, 2011). Skenario kegiatan pembelajaran yang mengacu pada indicator untuk mencapai hasil belajar yang sesuai dengan kurikulum berbasis kompetensi (KBK, 2004). Oleh karena itu, guru matematika SMPN 5 Batusangkar memulai melakukan modifikasi tujuan pembelajaran agar diperoleh RPP matematika berkarakter. Padahal tujuan pembelajaran harus dibuat berdasarkan $\mathrm{SK} / \mathrm{KD}$ dan indikator yang telah ditentukan (Supinah, 2008). Seharusnya pengembangan RPP berkarakter setidaknya dimulai dari adaptasi terhadap indikator pencapaian kompetensi seperti yang sudah dilakukan pada silabus matematika berkarakter. Bentuk modifikasi yang dilakukan oleh guru matematika pada rumusan tujuan pembelajaran yaitu dengan menambahkan nilai karakter yang sesuai diakhir kalimat rumusan tujuan pembelajaran tersebut.

Skenario kegiatan pembelajaran pada RPP matematika berkarakter SMPN 5 Batusangkar terbagi atas kegiatan pendahuluan, inti, dan penutup. Perancangan kegiatan pada skenario 
pembelajaran harus sesuai dengan metode pembelajaran yang sudah ditetapkan sebelumnya. Metode pembelajaran pada RPP matematika berkarakter di sekolah tersebut sudah bervariasi, seperti metode ceramah, inkuiri, tanya jawab, diskusi, penugasan. Metode-metode ini dipakai pada pembelajaran menggunakan model kooperatif (tipe STAD, Think Pair Share) dan pendekatan Contekstual Teaching Learning). Penentuan metode pembelajaran erat kaitannya dengan pemilihan strategi pembelajaran yang paling efisien dan efektif dalam memberikan pengalaman belajar yang diperlukan untuk membentuk karakter peserta didik (Mulyasa, 2011).

Kegiatan-kegiatan pada skenario pembelajaran mulai dari kegiatan awal sampai penutup sudah dirancang dalam rangka memberikan pengalaman seperti yang diungkapkan oleh Mulyasa di atas. Aktivitas-aktivitas yang memberikan pengalaman sehingga peserta didik terbiasa melakukan hal-hal positif (nilai karakter) pada skenario pembelajaran pada RPP tersebut diantaranya meminta peserta didik melakukan aktivitas matematika seperti menggali informasi, mempresentasikan, menyelesaikan masalah dan lain sebagainya. Tugas guru dalam rangcangan tersebut sebagai fasilitator, pembimbing, dan motivator. Menurut Suyanto, aktivitas tersebut termasuk aktivitas yang dapat mendorong autonomous learning dan bersifat learner-centered, serta membantu peserta didik memperoleh banyak nilai (Depdiknas, 2010).

Efektivitas rancangan kegiatan pembelajaran dapat diketahui dari hasil penilaian terhadap hasil belajar yang dicapai setelah kegiatan tesebut diimplementasikan. Menurut Mulyasa (2011), Efektivitas adalah bagaimana suatu organisasi berhasil mendapatkan dan memanfaatkan sumber daya dalam usaha mewujudkan tujuan operasional.
Masalah efektivitas biasanya berkaitan dengan perbandingan antara tingkat pencapaian tujuan dengan rencana yang telah disusun sebelumnya. Instrumen penilaian pada RPP matematika berkarakter menyediakan beberapa instrumen untuk mengukur pencapaian hasil belajar. Instrumen tes digunakan untuk mengukur kompetensi kognitif, lembar observasi untuk mengamati perkembangan nilai karakter yang sudah terinternalisasi pada diri peserta didik. Dengan dibuatnya instrument tersebut dapat disimpulkan bahwa guru telah merencanakan authentic assessment, karena instrumen yang dipilih tidak hanya mengukur kompetensi/ aspek kognitif saja, tetapi juga mengukur perkembangan kepribadian peserta didik (Zainal Arifin, 2009).

Langkah kedua implementasi pendidikan karakter yang terintegrasi pada mata pelajaran matematika, yaitu melaksanakan atau mengaplikasikan rencana strategis yang sudah dirancang dalam RPP. Kegiatan pembelajaran matematika di SMPN 5 Batusangkar lebih dihiasi dengan aktivitas mental peserta didik dalam menemukan konsep, memecahkan masalah dari konflik kognitif yang diberikan guru, mengkomunikasikan ide-ide matematika, membuat hubungan, dan menyajikan ide dan penyelesaian masalah serta memberika interpretasinya. Kegiatan yang demikian, menurut NCTM (2000) merupakan kegiatan pembelajaran matematika yang memenuhi prinsipprinsip dan standar matematika sekolah. Peran guru lebih banyak menfasilitasi peserta didik dalam melakukan unjuk kerja atau demonstrasi menemukan konsep. Contoh kegiatan unjuk kerja yang dilakukan peserta didik yaitu melakukan manipulasi terhadap sebuah bola sehingga, peserta didik dalam kelompoknya dapat menyimpulkan rumus luas permukaan bola. Pengalaman-pengalaman tersebut menjadi wahana untuk menanamkan nilai karakter; rasa 
ingin tahu, teliti, kreatif, kerjasama, tanggung jawab dan komunikatif (Armiati, 2011).

Selain menfasilitasi peserta didik, guru juga memberikan semangat kerja sehingga peserta didik selalu ingin menampilkan hasil kerja yang terbaik. Memberikan dorongan kepada peserta didik untuk menemukan konsep dan menerapkannya melalui praktik pembelajaran secara langsung merupakan suatu usaha pembentukan kompetensi dan karakter (Mulyasa, 2011). Selama pembelajaran berlangsung, guru mengamati secara individual ataupun kelompok perkembangan kompetensi dan nilai karakter yang berpedoman pada lembar observasi nilai karakter dan unjuk kerja. Penilaian perkembangan karakter peserta didik harus mengikuti prinsip berkelanjutan (Puskur, 2010). Oleh karena itu, kepala sekolah SMPN 5 Batusangkar membuat kebijakan yaitu setiap guru yang mengajar di kelas satu harus kembali mengajar peserta didik tersebut di kelas dua. Hal ini diberlakukan dengan pertimbangan agar guru dapat mengetahui perkembangan peserta didik secara terus-menerus.

Kunci sukses implementasi pendidikan karakter pada pembelajaran matematika tidak hanya didukung oleh persiapan dan pelaksanaan pembelajaran yang mengintegrasikan nilai-nilai karakter disetiap komponen silabus dan kegiatan pembelajaran, tetapi didukung juga oleh program pengembangan diri sekolah tersebut. Program pengembangan diri harus disesuaikan dengan visi dan misi sekolah. Program melaksanakan sholat dhuha, penyadaran disiplin masuk kelas tanpa adanya bunyi bel, membudayakan hidup bersih dan rapi merupakan wujud pembiasaan yang menjadi ciri khas SMPN 5 Batusangkar. Menurut Supinah (2010) kegiatankegiatan tersebut merupakan contoh pengembangan diri yang dapat dilakukan oleh sekolah sehingga pendidikan karakter terintegrasi pada setiap komponen sekolah.

Beberapa keterbatasan yang dialami guru matematika SMPN 5 Batusangkar dalam implementasi pendidikan karakter disebabkan karena keterbatasan buku pedoman atau panduan yang mereka miliki dan ketahui. Sumber mengakses informasi pelaksanaan pendidikan karakter hanya dari internet saja. Belum ada guru menerima panduan khusus tentang implementasi pendidikan karakter secara resmi dari diknas setempat. Implikasi keterbatasan ini ialah terdapat perbedaan pemahaman guru dalam mengimplementasi pendidikan karakter pada setiap mata pelajaran, khususnya mata pelajaran matematika. Oleh karena itu, Diknas atau pihak terkait perlu melakukan sosialisasi dan workshop tentang implementasi pendidikan karakter kepada guru-guru, karena sosialisasi berfungsi agar semua warga sekolah mengenal dan memahami visi dan misi sekolah serta pendidikan karakter yang akan diimplementasikan (Mulyasa, 2011).

\section{PENUTUP}

Implementasi pendidikan karakter pada pembelajaran matematika SMPN 5 Batusangkar sudah menyentuh tahap persiapan, pelaksanaan, dan penilaian. Kegiatan yang dilakukan pada tahap persiapan yaitu memodifikasi silabus dan RPP KTSP, sehingga terbentuk model silabus dan RPP pembelajaran matematika berkarakter.

Karakteristik kegiatan pembelajaran matematika di SMPN 5 Batusangkar dalam rangka meng-integrasikan nilai karakter yaitu meng-gunakan metode pencarían informasi, kerja kelompok, dan tanya jawab. Pembelajaran matematika dihiasi dengan aktivitas unjuk kerja, sedangkan peran guru lebih 
sebagai motivator dan pembimbing. Di setiap akhir pembelajaran, peserta didik dibiasakan melakukan refleksi dan evaluasi terhadap pengalaman belajar yang mereka alami. Model penilaian yang dilakukan guru matematika tidak hanya sebatas penilaian aspek kognitif saja, tetapi sudah menilai aspek afeksi (nilai karakter) dan psikomotor peserta didik.

\section{DAFTAR RUJUKAN}

Armiati, 2011. Integrasi pendidikan Karakter pada pembelajaran Matematika. Makalah dalam Workshop Implementasi Pendidikan Karakter Bangsa pada Guru Matematika SMP se-kota Padang pada Tanggal 2 Desember 2011.

Dispendik, 2010. Desain Induk Pembangunan karakter Bangsa Tahun 2010-2025. Pemerintah Republik Indonesia.

Erman Suherman, 2003. Common Text Book: Strategi Pembelajaran Matematika Kontemporer. Bandung: JICA-Universitas Pendidikan Indonesia (UPI).

Fajar Shadiq, 2007. Apa dan Mengapa Matematika begitu Penting?. Yogyakarta: Depdiknas.

Hamzah B. Uno, 2008. Model Pembelajaran. Jakarta: Bumi Aksara.

Lickona, Thomas, 2012. Education for Character. Diterjemahkan oleh Juma Abdu Wamaungo. Jakarta: Bumi Aksara.

Masnur Muslich, 2011. Pendidikan Karakter Menjawab Tantangan Krisis Multidimensional. Jakarta: Bumi Aksara

Mulyasa, H.E, 2009. Implementasi Kurikulum Tingkat Satuan Pendidikan (KTSP) pada Sekolah dan Madrasah. Jakarta: Bumi Aksara. , 2011. Implementasi Kurikulum Tingkat Satuan Pendidikan (KTSP)
Kendala yang dihadapi guru matematika SMPN 5 Batusangkar dalam mengimplementasikan pendidikan karakter pada pembelajaran matematika meliputi keterbatasan referensi tentang pengembangan perangkat pembelajaran matematika SMP berkarakter dan pedoman khusus yang berisi tentang penjelasan indikator nilai karakter untuk peserta didik SMP.

pada Sekolah dan Madrasah. Jakarta: Bumi Aksara

Muliyardi, 2002. Strategi Pembelajaran Matematika. Padang: Jurusan Matematika FMIPA UNP.

NCTM, 2000. Principles and Standards for School Mathematics. Reston, VA: Author.

PUSKUR, 2010. Buku Pedoman Pengembangan Pendidikan Karakter dan Budaya Bangsa. Jakarta: Dispendik

Permendiknas No. 22 tahun 2006 dan No. 41 tahun 2007

Sugiyono, 2007. Metode Penelitian Pendidikan. Bandung: Alfabeta.

Supiyah, 2011. Pengembangan Pendidikan Budaya dan karakter Bangsa Melalui Pembelajaran matematika. PPPPTK Kementerian Pendidikan Nasional.

Trianto, 2009. Mendesain Model Pembelajaran Inovatif Progresif. Jakarta: Fajar Interpratama Offset.

Undang-Undang SISDIKNAS No. 3 dan No. 20 Tahun 2003. Pemerintah Repuplik Indonesia.

Wahyudin, 2011. Membangun Karakter Melalui Pendidikan Matematika yang Berkualitas. Makalah Seminar Nasional Matematika VIII Himatika UNP Padang Tanggal 15 Oktober 2011. 

